\title{
Comparative Studies on Kisspeptin Receptor and their Physicochemical Characterization
}

\author{
Mukesh Kumar ${ }^{1 *}$, Gobinda Basumatary ${ }^{2}$, Roshan Kumar Ram ${ }^{1}$, Dilip Kumar Singh ${ }^{3}$ \\ and Uday Kumar Udit ${ }^{4}$
}

${ }^{1}$ Fish Genetics and Biotechnology Division, ICAR-Central Institute of Fisheries Education, PanchMarg, Off Yari Road, Mumbai, Maharashtra-400061, India

${ }^{2}$ College of Fisheries Raha, Nagaon, Assam Agricultural University, Assam-782103, India

${ }^{3}$ Fish Nutrition, Biochemistry and Physiology Division, ICAR-Central Institute of Fisheries Education, PanchMarg, Off Yari Road, Mumbai, Maharashtra-400061, India

${ }^{4}$ Fish Genetics and Biotechnology Division, ICAR-Central Institute of Freshwater

Aquaculture Kausalyaganga, Bhubaneswar, Odisha-751002, India

*Corresponding author

\section{A B S T R A C T}

\section{Keywords}

Zebra fish, Kisspeptin,

Kisspeptin receptor, Kiss I

gene, Hypothalamic

pituitary gonadal axis

\section{Article Info}

Accepted:

04 April 2018

Available Online:

10 May 2018

The kisspeptins are peptide hormones, having a critical role in the regulation of the hypothalamic-pituitary-gonadal axis, and important for reproduction. Kisspeptin which is the product of the Kissl gene and its receptor (GPR54 or Kiss1r) has now emerged as one of the key players in the regulation of reproduction. In this present work comparative study of Human, Rat, Zebra fish Kisspeptin receptor has been done. Insilco tools were used to describe the physiochemical, functional and structural properties of this receptor protein. Physico-chemical properties like as molecular weight, amino acid composition, isoelectric point, charge residue, Grand average of hydropathicity, instability index are computed. The studies give insight into kisspeptin receptor.

\section{Introduction}

The human kisspeptin gene was first identified as a melanoma metastasis suppressor gene (Lee et al., 1996) and with the help of inactivating mutations of its cognate receptor gene, KISS1R, which inhibited the pubertal development (Seminara et al., 2003) researcher found that both gene and its receptor are essential components of the mammalian reproductive system (Kauffman 2010). The isolation of KISS1 and KISS1R gene orthologs in a different organism like as in amphibians and fish etc. The study shows that conserved reproductive function of this ligand and receptor across vertebrates, having an exception in birds (Kim et al., 2012). The detailed study of kisspeptin and its receptor 
are beyond the limit of this research. In this present work we try to compare the rat, human and zebrafish kisspeptin receptor with the help of in silico tools.

\section{Materials and Methods}

Human (Ohtaki et al., 2001), Rat (Kotani et al., 2001) and zebra fish (Accession number F1R5R4 and F1QZU4) Kisspeptin receptor Sequence were selected and its protein fasta file was retrieved using NCBI and was used for further analysis.

\section{Physiochemical properties}

Physiochemical properties were calculated using Protparam tool (https://web.expasy. org/protparam/) (Gasteiger et al., 2005) which gives details about molecular weight, theoretical $\mathrm{Pi}$, amino acid composition etc. The amino acid composition was determined by using the protparam tool.

\section{Functional analysis and secondary structure analysis}

Transmembrane regions were identified using TMHMM Server v. 2.0 server. SOPMA (Geourjon et al., 1987) and GOR (Heymann et al., 2008) were used for predicting the secondary structure of the protein. In these tools the presence of alpha helx, pi helix, beta bridge, beta turn etc. is determined in terms of percentage.

The prediction of the protein structure was done using GPCR-I-TASSER (Zhang et al., 2015) which characterises various structural based templates from PDB database by various approaches that have various atomic based models. Ramchandran plot of the respective protein structure was determined by RAMPAGE (http://mordred. bioc.cam.ac.uk/ rapper/rampage.php) and the quality of the Ramchandran plot was characterised by WHAT IF SERVER (Vriend et al., 1990). For
Active binding site prediction $\mathrm{COACH}$ server were used.

\section{Results and Discussion}

In this presenter search four Kisspeptin receptor sequences were retrieved from NCBI and they are analysed computationally (Table 1). The primary structure analysis which means the Physico-chemical properties of this receptor was computed using Expasy's Prot Param tool and shown in Table 2. By analysing these we found that Alanine and Leucine amino acid are most abundant and the isoelectric point ( $\mathrm{pI})$ is the value at which the molecule carries no charges or/and positive negative charges is found to be equal. At a $\mathrm{pH}$ below their $\mathrm{pI}$ value of proteins carry a net positive charge; above their pI these carry a net negative charge. In our study this is highest for (Q969F8) and lowest value for F1QZU4 respectively all values in basic $\mathrm{pH}$ range. The Extinction coefficient (EC) at a $280 \mathrm{~nm}$ wavelength ranged from 63675 to 67380. The calculated extinction coefficient values help us in various quantitative studies of protein-protein and protein-ligand interactions in solution. The instability index value of proteins was computed by EsPasy protparam which gives an approximation of the stability of the protein in vitro. A protein whose instability index is smaller than 40 is predicted as stable, a value above 40 predicts that the protein may be unstable. The instability indexes of this receptor are ranging from 34.23 to 48.25 (Table 2). By analysing the instability index we can conclude that except Q969F8 other are stable The aliphatic index (AI) range from 93.20 to 103.05 which is the relative volume of a protein occupied by aliphatic side chains (A, V, I and L) is regarded as a positive factor for the increase of thermal stability of globular proteins. The lower thermal stability values indicate a more flexible structure when we compare with other receptors. 
Table.1 KISS receptor derived from NCBI database

\begin{tabular}{|l|l|l|}
\hline ACCESSION NUMBER & SEQUENCE DESCRIPTION & ORGANISM \\
\hline Q969F8 & KISSR_HUMAN KiSS-1 receptor & Homo sapiens \\
\hline Q924U1 & KISSR_RAT KiSS-1 receptor & Rattus norvegicus \\
\hline F1R5R4 & KISS1 receptor a danio & Danio rerio \\
\hline F1QZU4 & KISS1 receptor b danio & Danio rerio \\
\hline
\end{tabular}

Table.2 Amino acid composition of KISS receptor

\begin{tabular}{|l|l|l|l|l|}
\hline Amino acids & Q924U1 & Q969F8 & F1R5R4 & F1QZU4 \\
\hline Alanine A & 14.6 & 16.6 & 6.0 & 6.3 \\
\hline Arginine R & 7.1 & 7.8 & 4.9 & 4.4 \\
\hline Asparagine N & 2.8 & 2.8 & 4.1 & 4.4 \\
\hline Aspartic acid D & 2.0 & 2.0 & 2.7 & 2.2 \\
\hline Cysteine C & 3.8 & 3.8 & 2.7 & 4.1 \\
\hline Glutamine Q & 3.3 & 2.3 & 2.7 & 5.2 \\
\hline Glutamic acid E & 1.3 & 1.3 & 3.8 & 2.5 \\
\hline Glycine G & 5.6 & 6.3 & 4.1 & 2.5 \\
\hline Histidine H & 3.8 & 2.5 & 2.2 & 1.6 \\
\hline Isoleucine I & 1.8 & 1.5 & 8.5 & 6.6 \\
\hline Leucine L & 13.1 & 13.8 & 8.2 & 11.3 \\
\hline Lysine K & 1.0 & 1.3 & 4.6 & 2.2 \\
\hline Methionine M & 1.8 & 1.8 & 3.3 & 4.4 \\
\hline Phenylalanine F & 4.0 & 3.8 & 8.5 & 5.5 \\
\hline Proline P & 8.6 & 9.0 & 4.4 & 4.4 \\
\hline Serine S & 7.1 & 6.8 & 9.0 & 7.7 \\
\hline Threonine T & 4.8 & 3.5 & 6.0 & 8.2 \\
\hline Tryptophan W & 2.3 & 2.0 & 1.9 & 1.6 \\
\hline Tyrosine Y & 3.0 & 3.3 & 4.6 & 5.5 \\
\hline VALINE V & 8.3 & 8.0 & 7.7 & 9.3 \\
\hline
\end{tabular}

Table.3 Physicochemical properties of AFPs from different fish varieties are computed using Expasy's ProtParam tool

\begin{tabular}{|c|c|c|c|c|c|c|c|c|c|}
\hline $\begin{array}{c}\text { Accession } \\
\text { number }\end{array}$ & Length & $\begin{array}{c}\text { Molecular } \\
\text { Weight }\end{array}$ & $\begin{array}{l}\text { Isoelectric } \\
\text { point(PI) }\end{array}$ & $\begin{array}{c}\text { Negative } \\
\text { charged } \\
\text { Residue }\end{array}$ & $\begin{array}{c}\text { Positive } \\
\text { charged } \\
\text { Residue }\end{array}$ & $\begin{array}{l}\text { Extinction } \\
\text { coefficient }\end{array}$ & $\begin{array}{c}\text { Instability } \\
\text { index }\end{array}$ & $\begin{array}{c}\text { Aliphatic } \\
\text { index }\end{array}$ & GRA VY \\
\hline Q924U1 & 396 & 42889.14 & 9.70 & 13 & 32 & 67380 & 43.29 & 96.92 & 0.318 \\
\hline Q969F8 & 398 & 42586.04 & 9.93 & 13 & 36 & 64245 & 48.25 & 99.67 & 0.383 \\
\hline F1R5R4 & 366 & 42052.21 & 9.14 & 24 & 35 & 64455 & 34.23 & 93.20 & 0.271 \\
\hline F10ZU4 & 364 & 41578.00 & 8.67 & 17 & 24 & 63675 & 45.12 & 103.05 & 0.449 \\
\hline
\end{tabular}


Table.4 Transmembrane prediction results by TMHMM

\begin{tabular}{|l|l|l|l|l|l|l|l|}
\hline Accession number & TM1 & TM2 & TM3 & TM4 & TM5 & TM6 & TM7 \\
\hline Q969F8 & $44-66$ & $79-101$ & $121-138$ & $158-180$ & $204-226$ & $264-286$ & $306-328$ \\
\hline Q924U1 & $44-66$ & $79-101$ & $121-138$ & $158-180$ & $204-226$ & $261-283$ & Nil \\
\hline F1R5R4 & $40-62$ & $75-97$ & $112-131$ & $152-174$ & $202-224$ & $260-282$ & $297-319$ \\
\hline F10ZU4 & $46-68$ & $89-111$ & $124-146$ & $158-180$ & $208-230$ & $271-293$ & $308-330$ \\
\hline
\end{tabular}

Table.5 Secondary structure prediction by GOR server in percentage

\begin{tabular}{|l|l|l|l|l|}
\hline Accession Number & Alpha helix & Extended & Beta turn & Random coil \\
\hline Q924U1 & 28.79 & 18.43 & 0.00 & 52.78 \\
\hline Q969F8 & 34.92 & 15.08 & 0.00 & 50.00 \\
\hline F1R5R4 & 25.68 & 28.69 & 0.00 & 45.63 \\
\hline F1QZU4 & 15.11 & 36.54 & 0.00 & 48.35 \\
\hline
\end{tabular}

Table.6 Secondary structure prediction by SOPMA server in percentage

\begin{tabular}{|l|l|l|l|l|}
\hline Accession Number & Alpha helix & Extended & Beta turn & Random coil \\
\hline Q924U1 & 41.92 & 14.39 & 2.53 & 41.16 \\
\hline Q969F8 & 42.46 & 13.82 & 4.02 & 39.70 \\
\hline F1R5R4 & 41.26 & 15.57 & 2.46 & 40.71 \\
\hline F10ZU4 & 47.80 & 15.93 & 2.20 & 34.07 \\
\hline
\end{tabular}

The very high aliphatic index infers that these receptor may be eurythermal means having a wide range of temperature tolerance (Table 3). The Grand Average Hydropathy (GRAVY) is a phenomenon used for calculating the hydropathy value of all the amino acids upon the number of residues in the sequences. Fish kisspeptn receptor proteins analysed in this study having a range from 0.271 to 0.449 . We also performed trans-membrane (TM) region identification with the help of TMHMM Server v. 2.0.

This helps in the identification of various transmembrane helices with their corresponding length and it helps to distinguish between membrane proteins from stable proteins. All are seven trans-membrane helices but theoretically Q924U1 showing six trans-membrane which is not acceptable (Table 4).

The KISS peptin receptor is seven transmembrane $\mathrm{G}$ protein coupled receptor reported by several researchers. The secondary structures of AFPs were predicted by SOPMA (Table 5) and GOR (Table 6).

Ramchandarn plot validation of is done and allowed and disallowed region is calculated. Most of the amino acid found in the allowed region. For the study the receptor-ligand interaction the identification of ligand binding sites is an important parameter and there are no individual methods that can provide the optimal prediction for all proteins (Kumar et al., 2018).COACH server (Jianyi et al., 2013) has used to identify the active binding site of this receptor.

\section{References}

Gasteiger, E., Hoogland, C., Gattiker, A., Wilkins, M.R, Appel, R.D., Bairoch, A. (2005) Protein identification and analysis tools on the ExPASy server. In the 
proteomics protocols handbook, Pp. 571607.

Geourjon, C. and Deleage, G., (1995) SOPMA: significant improvements in protein secondary structure prediction by consensus prediction from multiple alignments. Bioinformatics, 11(6):681684.

Heymann, M., Paramelle, D., Subra, G., Forest, E., Martinez, J., Geourjon, C., Deléage, G., MSX (2008) 3D: a tool to validate 3D protein models using mass spectrometry. Bioinformatics, 24(23): 2782-3.

Jianyi Yang, Ambrish Roy and Yang Zhang, (2013) Protein-ligand binding site recognition using complementary binding-specific substructure comparison and sequence profile alignment. Bioinformatics, 29: 2588-2595.

Kauffmann AS (2010) Coming of age in the kisspeptin era: sex differences, development, and puberty. Mol Cell Endocrinol 324:51-63.

Kim DK, Cho EB, Moon MJ, Park S, Hwang JI, Rego JLD, Vaudry H, Seong JY (2012) Molecular coevolution of neuropeptides gonadotropin-releasing hormone and kisspeptin with their cognate $\mathrm{G}$ proteincoupled receptors. Front Neurosci 6:1-8.

Kotani, M., Detheux, M., Vandenbogaerde, A., Communi, D., Vanderwinden, J.M., Le Poul, E., Brézillon, S., Tyldesley, R., Suarez-Huerta, N., Vandeput, F. and Blanpain, C., (2001). The metastasis suppressor gene KiSS-1 encodes kisspeptins, the natural ligands of the orphan G protein-coupled receptor GPR54. Journal of Biological Chemistry, 276(37), pp.34631-34636.

Kumar, M., Saldana, H., Ram, R.K., Bhattacharyya, H. and D.' Souza, N.,
(2018) In-Silco Analysis of Fish Antifreeze Proteins and Their Physicochemical Characterization, Int. J. Pure App. Biosci. 6(1): 1392-1398.

Lee JH, Miele ME, Hick DJ, Philips KK, Trent JM, Weissman BE, Welch DR (1996) KiSS-1, a novel human malignant melanoma metastasis-suppressor gene. $\mathbf{J}$ Natl Cancer Natl Cancer Inst 88:17311737.

Ohtaki, T., Shintani, Y., Honda, S., Matsumoto, H., Hori, A., Kanehashi, K., Terao, Y., Kumano, S., Takatsu, Y., Masuda, Y. and Ishibashi, Y. (2001.) Metastasis suppressor gene KiSS-1 encodes peptide ligand of a G-protein-coupled receptor. Nature, 411 (6837), p.613.

Seminara SB, Messager S, Chatzidaki EE, Thresher RR, Acierno JS, Shagoury JK, Bo-Abbas Y, Kuohung W, Schwinof KM, Hendrick AG, Zahn D, Dixon J, Kaiser UB, Slaugenhaupt SA, Gusella JF, O'Rahilly S, Carlton MB, Crowley WF Jr, Aparicio SA, Colledge WH (2003) The GPR54 gene as a regulator of puberty. N Eng J Med 349:1614-1627.

Sigrist, C.J.A., de Castro, E., Cerutti, L., Cuche, B.A., Hulo, N., Bridge, A., Bougueleret, L., Xenarios, I., (2012) New and continuing developments at PROSITE Nucleic Acids Res. Vriend, G., (1990) WHAT IF: a molecular modeling and drug design program. Journal of molecular graphics, 8(1): 52-61.

Zhang, J., J Yang, R Jang, Y Zhang (2015) GPCR-I-TASSER: A hybrid approach to $\mathrm{G}$ protein-coupled receptor structure modeling and the application to the human genome, Structure, 23: 1538-1549.

\section{How to cite this article:}

Mukesh Kumar, Gobinda Basumatary, Roshan Kumar Ram, Dilip Kumar Singh and Uday Kumar Udit. 2018. Comparative Studies on Kisspeptin Receptor and their Physicochemical Characterization. Int.J.Curr.Microbiol.App.Sci. 7(05): 43-47. doi: https://doi.org/10.20546/ijcmas.2018.705.006 